\title{
Role of River-Flow in Alleviating Heavy Metal Load from a Polluted Urban River
}

\author{
Md. Arifur Rahman ${ }^{1}$, Syed Hafizur Rahman ${ }^{2 *}$, \\ M. Alamgir Zaman Chowdhury ${ }^{3}$ \\ ${ }^{1}$ Military Institute of Science and Technology (MIST), Bangladesh Military Academy (BMA), \\ Bhatiary, Chittagong-4217, Bangladesh \\ ${ }^{2}$ Department of Environmental Sciences, Jahangirnagar University, Dhaka-1342, Bangladesh \\ ${ }^{3}$ Agrochemical and Environmental Research Division (AERD), Institute of Food and Radiation Biology (IFRB), Savar, \\ Dhaka-1349, Bangladesh
}

Received: 26 November 2020

Accepted: 20 January 2021

\begin{abstract}
Optimum water flow is inevitable for river health protection. Urban rivers around Dhaka city, Bangladesh, is heavily polluted by numerous chemical pollutants including heavy metals. This study investigated heavy metals concentration and river-flow volume to elucidate the relationship between them. River-flow and metals analysis $(n=672$ water samples) was performed for two consecutive years (November, 2017- October, 2019) in both the dry- and wet-seasons. The metal was analyzed by AAS, and Water-flow was measured by the formula of 'velocity dimensional'. It was observed that, in the dry-period (November to May), the water-flow of the river ranged from $12.76 \mathrm{~m}^{3} / \mathrm{sec}$ to $49.87 \mathrm{~m}^{3} / \mathrm{sec}$, whereas, in the wet-period (June to October), it was $35.39 \mathrm{~m}^{3} / \mathrm{sec}$ to $183.48 \mathrm{~m}^{3} / \mathrm{sec}$. In the dry-period, the concentration of $\mathrm{Cr}, \mathrm{Cd}, \mathrm{Pb}$, and $\mathrm{Ni}$ was found 3,860\%, $12,900 \%, 8,200 \%$, and 3,300\%, respectively higher than the permissible limits. Optimum water-flow, $\geq 49.87 \mathrm{~m}^{3} / \mathrm{sec}$, can run-down these metals from the river both in the dry- and wet-periods to retain environmental balance throughout the year. The proposed modeling of the optimum water-flow to minimize heavy metals concentration would be a promising measure to tackle the risk of the world's urban rivers.
\end{abstract}

Keywords: communal method, metal concentration, optimum flow, urban river, water-flow

\section{Introduction}

Environmental flow is required to ensure the ecosystem, as well as the survival of aquatic life in the urban river [1]. However, rivers in urban areas around the world continued to be polluted by untreated

*e-mail: hafizsr@juniv.edu wastewater from industrial and domestic sources. As a result, the degree of physicochemical parameters, especially the concentration of heavy metals (HMs) in urban rivers, has reached alarming levels [2, 3]. Buriganga and Turag rivers of Bangladesh, Citarum River of Indonesia, Sarno River of Italy, Pasing River of Manila, Cuyahuga River of USA, and Buddha Nulla River of India, etc. are the best possible examples of urban polluted rivers. 
Heavy metals (HMs) are dangerous because they tend to bio-accumulate. Since the toxicity of HMs precipitates over time, an immediate regression of their concentration is essential [4, 5]. Aside from the environmental flow, a "certain amount" of the water flow can inhibit metals from forming poorly soluble inorganic compounds and burying them in sediments. Therefore, the water flow can keep a vital role in removing metal concentration. However, with the loss of water flow, the worst level of contamination is generally found in urban rivers [6].

Contamination of HMs in river water has been found at an alarming level [7, 8] because untreated wastewater sources are increasing with unplanned urbanization, population growth, and massive industrialization around the urban rivers. The concentration of HMs in river water can pose adverse risks to the ecosystem; [9, 10, 11]. The excessive use of HMs in industries around the river bank poses a greater risk of pollution of river water. Thus, HM concentrations in the water can continue to increase.

Many urban rivers around the world have been exposed to HMs contamination in their sediment and basins, surface water, and in the food chain. For example, the water quality and seasonal variations of Nile River of Egypt and Odiel River of South-West Spain was assessed in terms of HMs concentration [12, 13]. The existence of $\mathrm{Zn}, \mathrm{Fe}, \mathrm{Mn}, \mathrm{Cu}, \mathrm{Cd}, \mathrm{Pb}$, and $\mathrm{As}$ was confirmed with much lower quantities. Similar variations have also been studied for the Siahroud River of Iran [14], Indus River of Pakistan [15] and the Bramani River of India [16]. With a different analysis direction, a study was conducted to find out the concentration, stability, risk assessment, and source apportionment of HMs of the Songhua River in the Harbin region of Northeast China [17]. Another study demonstrated the contamination of Buriganga in Bangladesh [18].

However, to improve the water quality of urban rivers, many developed countries have implemented aeration, water diversion, sediment dredging, and flocculation methods [19]. For example, the river aeration technology has been used in the Oerias River in Portugal, the Emsche River in Germany, the Thames River in the UK and the Homewood canal in the United States [20]. Moreover, sediment dredging has been implemented into many rivers around the world, such as the UK port-channel and Xuan Wu Lake in China [21]. In addition to the technology used in developed countries, retaining an optimum water-flow in urban rivers can be an option to minimize the concentration of heavy metals in urban rivers.

This paper, therefore, elucidated the water-flow and a set of HMs in Turag river, which is one of the most polluted rivers in and around Dhaka city, to find out optimum water-flow, which will run-down HMs of the river to retain sustainable water quality.

\section{Materials and Methods}

\section{Study Area}

Bangladesh is a very small but one of the most populated riverine countries in the world. The Turag is one of the most polluted urban rivers, surrounded by numerous industries and population growth. Department of Environment (DoE), Bangladesh, has declared the river as ECA (Ecologically Critical Area) to save its ecology in September 2009 [22]. A $4 \mathrm{~km}$ long strip of river Turag was investigated where sampling sites (SS) were selected based on the bend and width of the river, population growth, surrounding industries, farmland, and slum (Fig. 1). The distance from one SS to another SS was $1 \mathrm{~km}$. The width of the river (in the study area) was in the range of 20 to $25 \mathrm{~m}$. The depths vary from $5 \mathrm{~m}$ to $3 \mathrm{~m}$ in the wet to dry season. Zone temperature varies from $16^{\circ} \mathrm{C}$ to $36^{\circ} \mathrm{C}$. Longitude, latitude, and distance from pollution sources of the area are also illustrated in Table 1.
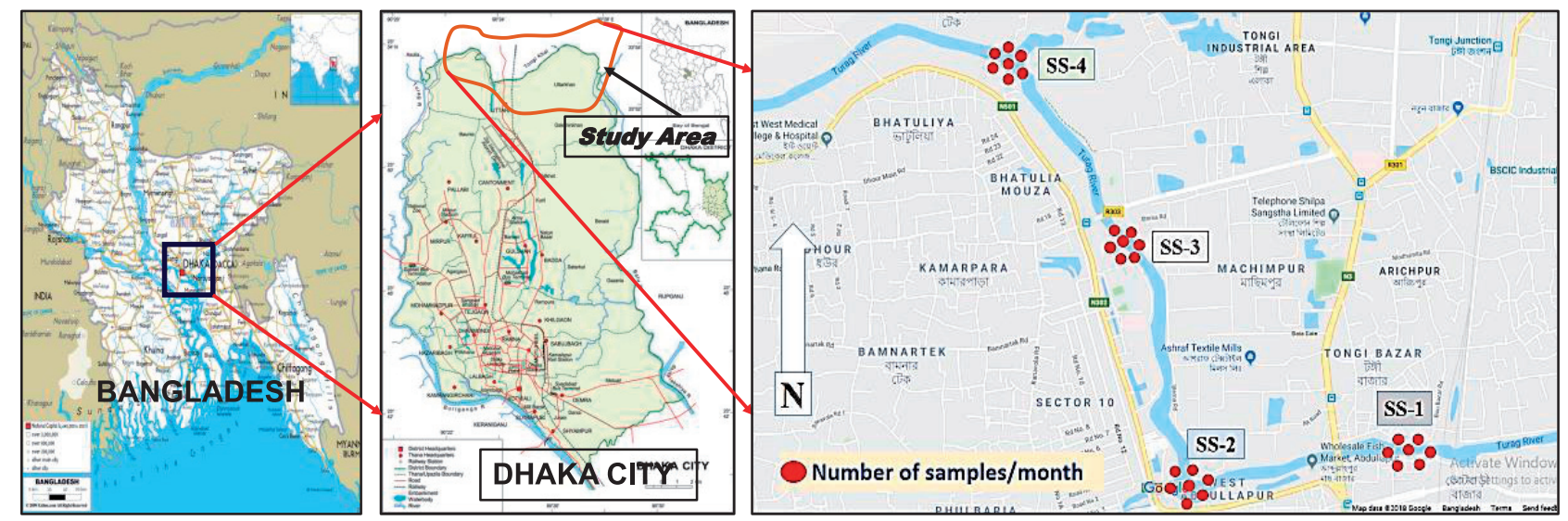

Fig. 1. Area of study and the locations of sample collection in Turag River, Bangladesh (courtesy: Google map). 
Table 1. Study area specifications.

\begin{tabular}{|c|c|c|c|}
\hline Location & Longitude & Latitude & Distance* \\
\hline SS-1 & $90^{0} 24^{\prime} 3.389^{\prime \prime} \mathrm{E}$ & $23^{0} 52^{\prime} 54.65^{\prime \prime} \mathrm{N}$ & $20 \mathrm{~m}$ \\
\hline SS-2 & $90^{0} 23^{\prime} 32.51^{\prime \prime} \mathrm{E}$ & $23^{0} 53^{\prime} 11.09^{\prime \prime} \mathrm{N}$ & $524 \mathrm{~m}$ \\
\hline SS-3 & $90^{0} 23^{\prime} 23.43^{\prime \prime} \mathrm{E}$ & $23^{0} 53^{\prime} 29.61^{\prime \prime} \mathrm{N}$ & $43 \mathrm{~m}$ \\
\hline SS-4 & $90^{0} 23^{\prime} 10.51^{\prime \prime} \mathrm{E}$ & $23^{0} 53^{\prime} 50.08^{\prime \prime} \mathrm{N}$ & 5 \\
\hline
\end{tabular}

*Minimum distance from the nearby industrial areas (measured from the Google map)

\section{Pollution Sources}

In general, the pollution point sources of Turag River are mainly industrial effluents and municipal waste, and the non-point sources are agricultural runoff and others. Industrial effluents are mostly textile, tannery, dyeing, and pharmaceuticals. DoE \& LGED. 2010 reported that the Turag River received discharges from all the industries that include more than 23 heavy industries including textiles, footwear, food, chemical, pharmaceutical, and detergents. This cluster of industries generates daily more than $7,000 \mathrm{~kg}$ of effluents [23].

\section{Sample Collection, Preservation, and Analysis}

A total of 28 water samples were collected each month (from November 2017 to October 2019) from four sampling sites, i.e., two samples from each bank and three samples from the middle of the river for each site (see small dots in Fig. 1). A seasonal study was conducted in the dry and wet periods (NovemberMay: the dry period, June-October: the wet period) of each year. Therefore, a total of 672 samples (i.e., 336 samples per year) were collected. Water-flow was measured by the formula 'dimensions of velocity' (Eq. 1) using technical support from the Bangladesh Water Development Board.

$$
V=0.25639 \mathrm{~N} / 100+0.00339 \mathrm{~m}^{3} / \mathrm{sec}
$$

...where, $V=$ velocity and $N=$ number of revolution

The water samples were collected in $500 \mathrm{ml}$ plastic bottles, which were sterilized before sample collection to avoid contamination. They were cleaned with a detergent solution followed by overnight treatment with 5\%, and a final wash using de-ionized water repeated a couple of times. After the collection of samples, those were sealed and preserved at to prevent the risk of hydrolysis and oxidation. The bottles were kept airtight and labeled individually for documentation. The sample-water in each bottle was digested with nitric acid and filtered by Whatman-41 $(0.45 \mu \mathrm{m}$ pore size) filter paper for a guesstimate of dissolved metal content. Moreover, it was kept at room temperature with $2 \mathrm{ml}$ nitric acid to resist the precipitation of metals. A test volume of $50 \mathrm{ml}$ sample was transferred into a clean glass, and concentrated was added for its digestion. The temperature was kept to heat the solution until dry without boiling. After cooling down, distilled water was used to dilute the samples and made a volume of $50 \mathrm{ml}$ in a volumetric flask. Finally, the samples were aspirated into an air acetylene flame in the AAS (Shimadzu AA6300) of the Bangladesh Atomic Energy Research Establishment (AERE).

The metal content, $M C$ of the sample, is finally determined using Eq. (2), where $C$ is the concentration of the metal determined by the AAS, and $W$ is the weight of the sample. The numerical data of the HM concentration and water-flow were statistically processed, analyzed, and represented using the MATLAB application (R2016b v.9.1.0441655).

$$
M C=C / W \times 100(\mathrm{ppm})
$$

\section{Results and Discussion}

\section{Impact of Cumulative Heavy Metals Concentration}

The present study has recorded progressively higher concentrations of the HMs compared to the earlier studies. Thus, an imminent endangerment to aquatic life and the territorial environment has been revealed. More quantitative details of the concentration levels are given in Table 2 and Table 3. The assessed amount of $\mathrm{Cr}, \mathrm{Cd}, \mathrm{Pb}$, and $\mathrm{Ni}$ is found to be 3,860\%, $12,900 \%, 8,200 \%$, and 3,300\% higher than the limits of Bangladesh Standard [24].

Compared with Bangladesh standard of the respective heavy metals, it was observed that concentrations of heavy metal had reached a critical state. For example, in 2017-2018, the highest value of Fe was found at $3.826 \mathrm{ppm}$ in March 2018. Contrariwise, in 2018-2019, the highest concentration of Fe was found 3.390 ppm in April 2019 (Fig 2). It is evident that the highest concentration was found in the dry period of both years. The concentrations of the $\mathrm{Cu}$ and $\mathrm{Zn}$ were within the permissible limit in the entire period of our study. 

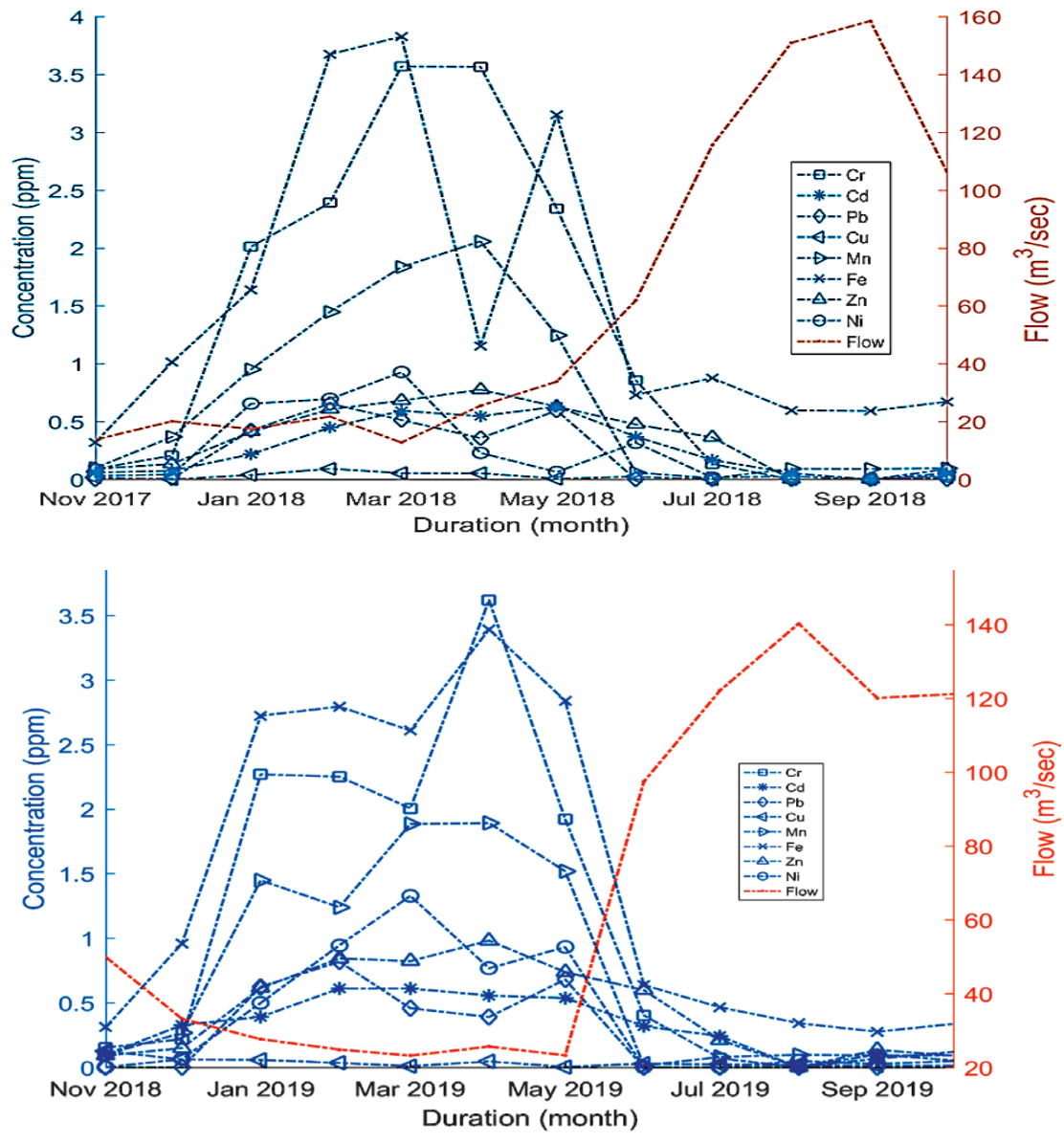

Fig. 2. Impact of water-flow on HM concentrations of Turag River in the year of a) 2017-18 and b) 2018-2019.

\section{Impact of Plummeting Water-Flow}

The monthly water flow for the study period has been shown in Table 2 and in Table 3. Compared to the previous cases, it has been found that the river flow has decreased sharply in the last two decades. For example, see Table 4, the lowest and highest water flows were recorded at $180.77 \mathrm{~m}^{3} / \mathrm{sec}$ and $556.85 \mathrm{~m}^{3} / \mathrm{sec}$, respectively, in 1989-2004. In the next five years, the lowest flow decreases by $65.8 \%$ and the highest flow decrease by about $16 \%$. In 2016-2017, the volume of water flow decreased to $6.99 \mathrm{~m}^{3} / \mathrm{sec}$ in the dry period. This means that the rate of water flow reduction is greater than $80 \%$ of the initial water flow measured in 1989-2004. However, the lowest and highest water flow in the current study showed a very miserable condition of $12.76 \mathrm{~m}^{3} / \mathrm{sec}$ and $158.47 \mathrm{~m}^{3} / \mathrm{sec}$ respectively.

The HMs concentration and the water-flow are reversely found (Fig. 2). In a dry season, the flow-rate of the river naturally reduces. However, it increases in wet seasons. In contrast, the concentration of HMs has a declining trend in the wet season and vice-versa. For example, the highest Cd-concentration was found in May 2018 (0.629 ppm), when the water flow was $33.82 \mathrm{~m}^{3} / \mathrm{sec}$, although it was gradually reduced with increasing water-flow up to $158.47 \mathrm{~m}^{3} / \mathrm{sec}$. The Cd- concentration was found Below the Detection Level (BDL) in September 2018, when the water-flow was $158.47 \mathrm{~m}^{3} / \mathrm{sec}$. A similar effect of water-flow exists on other HMs.

With another example, in Fig. 2, it was observed that the highest concentration of $\mathrm{Pb}$ was found 0.818 ppm in February 2019 in the dry period, when the water-flow was $24.82 \mathrm{~m}^{3} / \mathrm{sec}$. The value was higher than the Bangladesh standard (0.5 ppm) like Cd. In the wet period, the concentration was BDL. This trend in the concentration holds for other metals as well.

\section{Analysis of Concentration of HMs with Water-Flow}

In Fig. 3, the average concentration of the metals was plotted over the average water-flow, where the flow is normalized by a mean of 44.02 and a standard deviation of 55.02. An analytical relationship between concentration and water-flow is estimated in Eq. (2) at $95 \%$ confidence interval using MATLAB polynomial curve-fitting toolbox. We found that a fifth-degree polynomial would reasonably capture the empirical relation between the HMs concentration and water-flow. We computed the flow-coefficients $(P)$ in Table 5 for this model utilizing the HMs concentration and water-flow evaluated in our study. Thereby, 


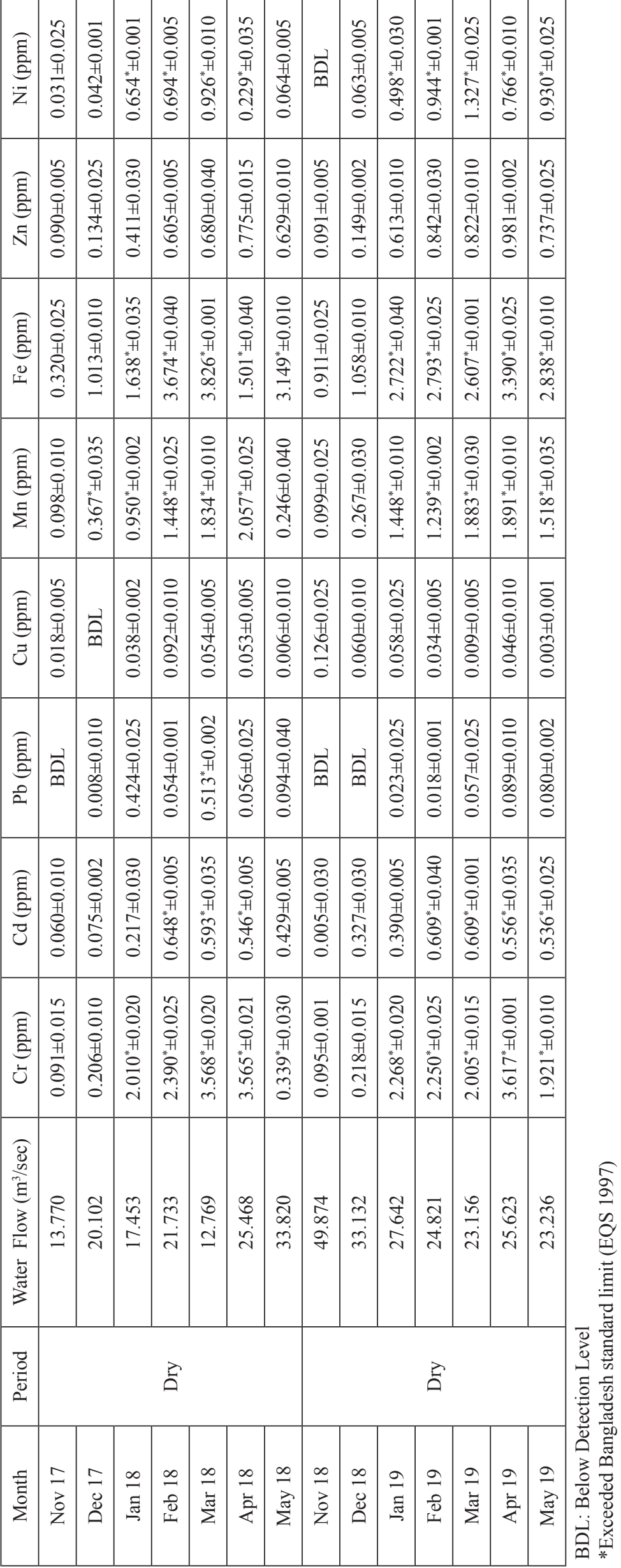




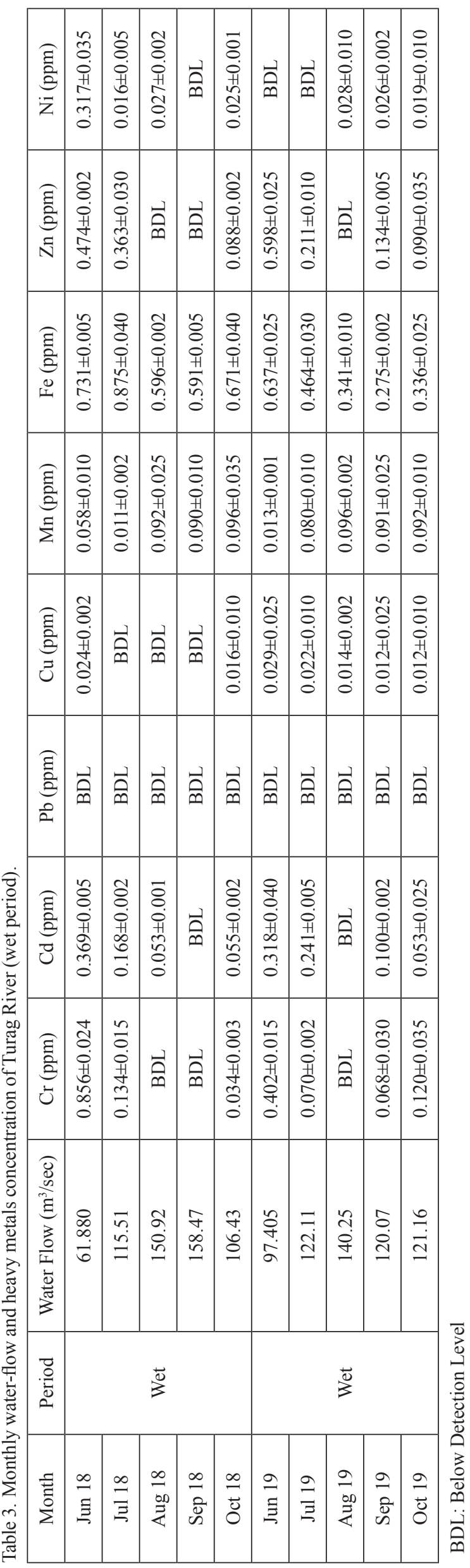

the minimum required water-flows for the permissible concentrations of individual metals are determined.

$$
C=P_{1} * f^{4}+P_{2} * f^{3}+P_{3} * f^{2}+P_{4} * f+P_{5}
$$

The minimum required water-flow is determined in two steps. First, the individual concentrations of the metals are determined to their known permissible limits. For example, see Fig. 3, the required minimum flow for $\mathrm{Cr}$ was found $17.90 \mathrm{~m}^{3} / \mathrm{sec}$ for the permissible concentration of $0.5 \mathrm{ppm}$. Thus, the minimum required flows found for other metals are 7.82, 21.5, $50.0,33.2$, and $44.30 \mathrm{~m}^{3} / \mathrm{sec}$ for $\mathrm{Cd}, \mathrm{Pb}, \mathrm{Mn}, \mathrm{Fe}$, and $\mathrm{Ni}$, respectively. Therefore, according to the graphical presentation, when the river could maintain its waterflow of more than $50 \mathrm{~m}^{3} / \mathrm{sec}$, manganese present in the river will reach into an allowable limit. Since all the results found in the illustration were less than $50 \mathrm{~m}^{3} / \mathrm{sec}$, it is obvious that a water-flow of $50 \mathrm{~m}^{3} / \mathrm{sec}$ is also able to reduce the concentration of other HMs to the permissible limit, which supports the experimental findings of optimum required water-flow into the Turag River. Note that the minimum required flows of $\mathrm{Cu}$ and $\mathrm{Zn}$ were not found, as their concentrations always remained within permissible limits.

\section{Discussion}

To the best of our knowledge, this is the first study that examined the role of river-flow on HMs load reduction quantitatively in Bangladesh. The rapid expansion of urbanization and industrialization has an impact on river flow regime along with the other hydro geomorphological factors. In this study, we hypothetically took river-flow as a pivotal factor to reduce HM load in the urban river to examine through field data analysis for two consecutive years. Usually, during the course of HM transportation, it undergoes a set of processes including speciation, deposition, dissolution, precipitation, and sorption [25]. Not surprisingly, when comparing with the other urban rivers around the world, it was observed that most of the considered HMs are present in the Turag's water at a much higher level. Unlike the Odiel River in Spain, where $\mathrm{Zn}, \mathrm{Cu}, \mathrm{Mn}$, and $\mathrm{Fe}$ were recorded at their highest levels, Turag recorded the secondhighest levels of all the metals. High loading of HMs negatively impacts on the river ecosystem health. The Government of Bangladesh has been looking for a suitable way to alleviate the pollution from the urban river for ecosystem restoration. But the outcome of the restoration program is not visible yet due to multilateral factors. Under the circumstance, natural river-flow regime re/installation could be a suitable option to achieve a large-scale pollution abatement goal. Therefore, this experimental study might shed light on the crucial role of river flow to remediate HM pollution load through dissolution phenomena. Here, to find out the optimum flow of water, initially, the optimum flow 
a)

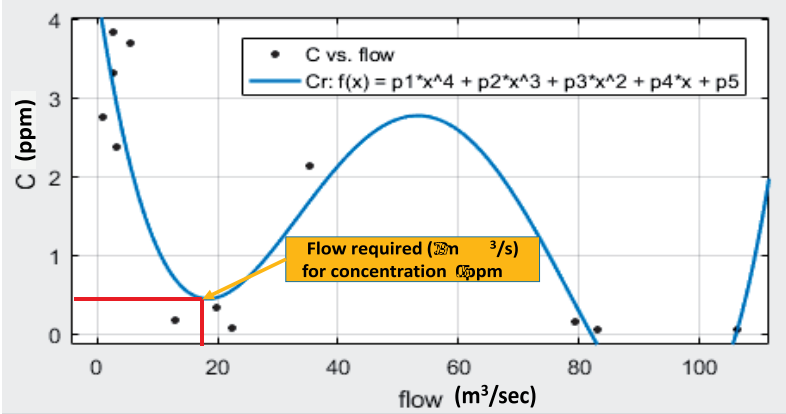

c)

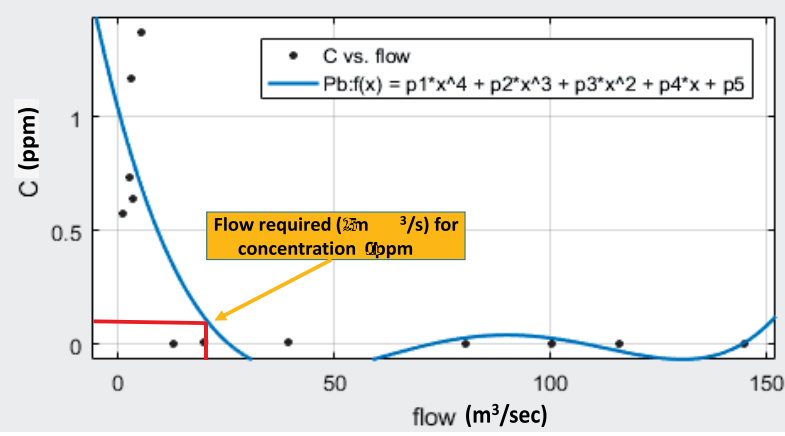

e)

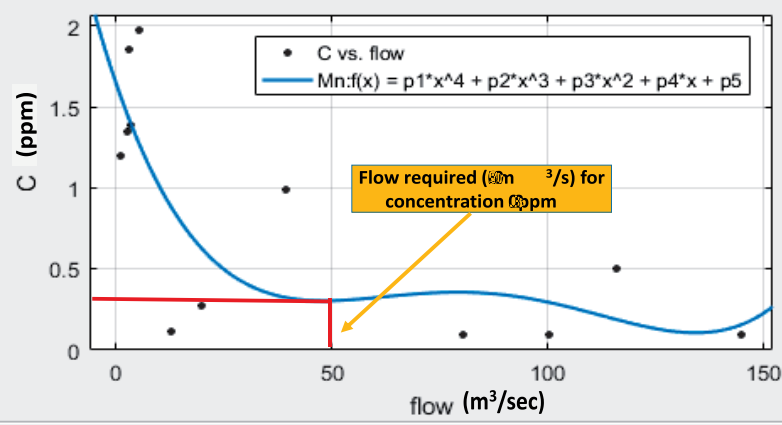

g)

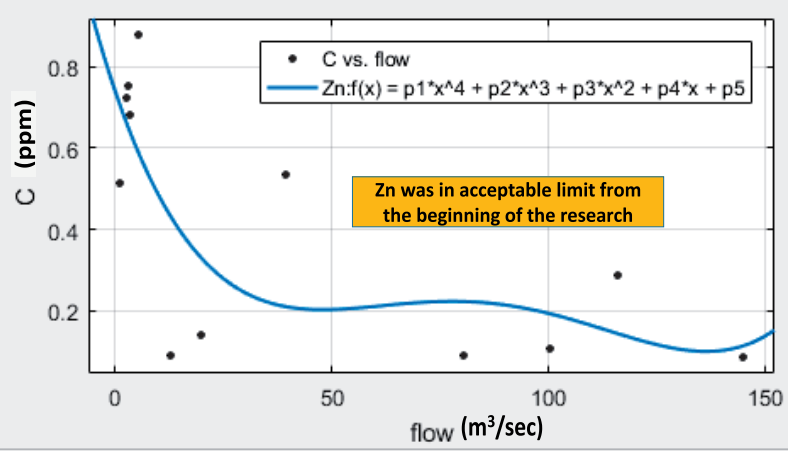

b)

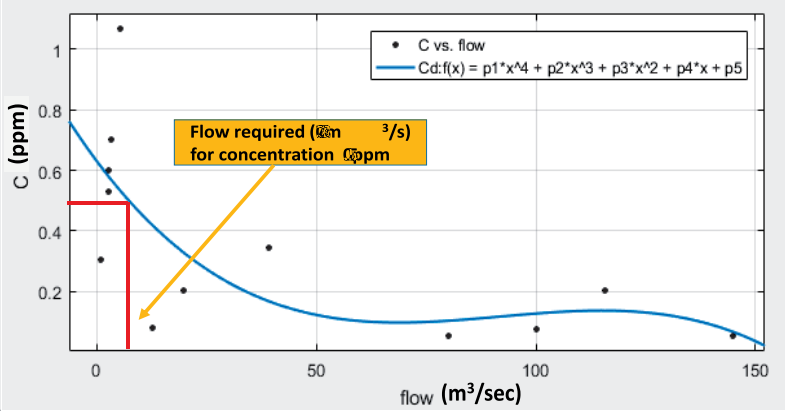

d)

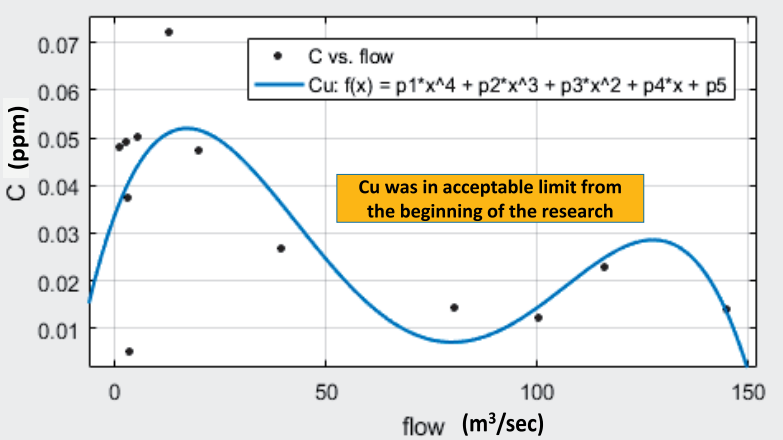

f)

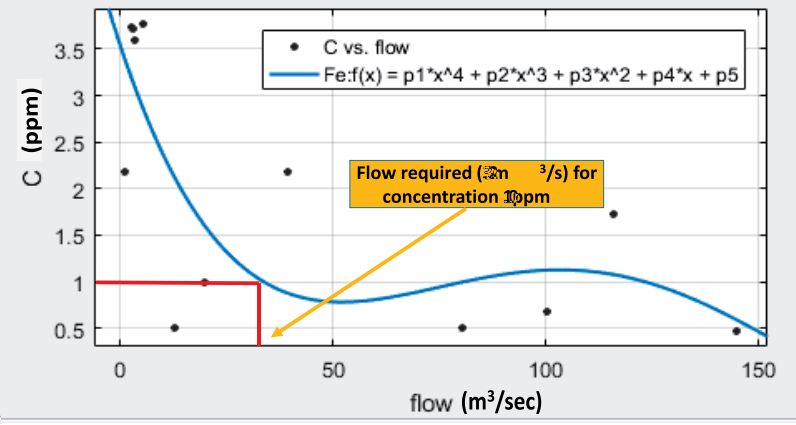

h)

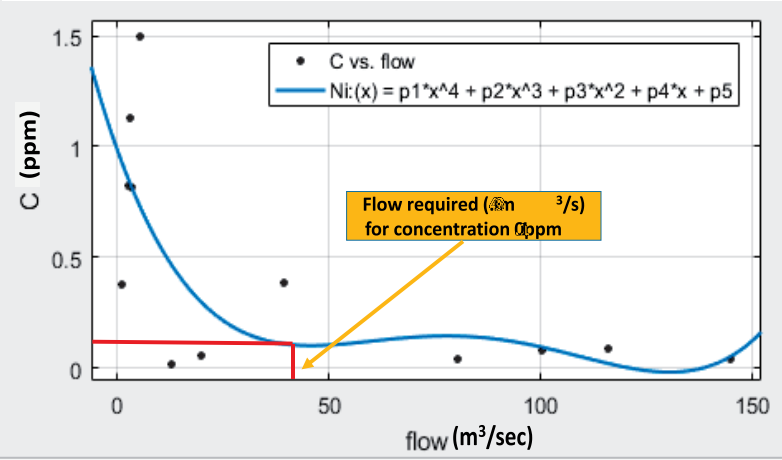

Fig. 3. Analytical presentation of concentration (C) in ppm of (a) $\mathrm{Cr}$, (b) Cd, (c) $\mathrm{Pb}$, (d) $\mathrm{Cu}$, (e) Mn, (f) Fe, (g) $\mathrm{Zn}$ and (h) Ni with water flow in $\mathrm{m}^{3} / \mathrm{sec}$.

of an individual metal is determined via statistical modeling (Fig. 3). Thereafter, the overall optimum flow is analytically determined as its highest value. For example, as mentioned in Table 6, the highest of the individual minimum flow is $49.87 \mathrm{~m}^{3} / \mathrm{sec}$ (for $\mathrm{Fe}$ ). Thus, the optimum flow of $49.87 \mathrm{~m}^{3} / \mathrm{sec}$ is a discretionary requirement in general for all metals to run-down and remain within permissible limits. Practically it was also observed that all the metals remain within their limits with that flow, as evident in Table 2 (Nov 18). 
Table 4. Current state of the water-flow in the Turag River.

\begin{tabular}{|c|c|c|}
\hline \multirow{2}{*}{ Duration } & \multicolumn{2}{|c|}{ Water Flow $\left(\mathrm{m}^{3} / \mathrm{sec}\right)$} \\
\cline { 2 - 3 } & Minimum & Maximum \\
\hline $1989-2004[1]$ & $180.77^{\mathrm{a}}$ & $556.85^{\mathrm{b}}$ \\
\hline $2005-2009[1]$ & $62.33^{\mathrm{a}}$ & $467.82^{\mathrm{b}}$ \\
\hline $2016-2017[6]$ & $6.99^{\mathrm{a}}$ & $93.05^{\mathrm{b}}$ \\
\hline $\begin{array}{c}2017-2019 \\
\text { (Present Study) }\end{array}$ & $25.75^{\mathrm{a}}$ & $119.42^{\mathrm{b}}$ \\
\hline
\end{tabular}

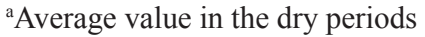

${ }^{\mathrm{b}}$ Average value in the wet periods

A line of evidence from a global database represents the role of high river-flow on HMs load reduction for instance, the concentration of heavy metals in the Nile was found to be within the permissible limit while the water-flow was $84 \mathrm{bcm} / \mathrm{yr}$ (over $49.87 \mathrm{~m}^{3} / \mathrm{sec}$ ). The concentration of heavy metals in the Brahmini River was observed within the WHO standard limit, while the water flow was found to be $19,457 \mathrm{~m}^{3} / \mathrm{sec}$ in the wet period (over $49.87 \mathrm{~m}^{3} / \mathrm{sec}$ ). Likewise, being one of the most polluted rivers in the world, heavy metal concentration of Citarum River, Indonesia, has been found within acceptable limit due to the maintenance of water-flow of $78.74 \mathrm{~m}^{3} / \mathrm{sec}$ [26]. On the other hand, HMs concentration of Sarno River, Italy, the most polluted river of Europe [27], was found higher than the standard limit owing to very low water-flow (13 $\mathrm{m}^{3} / \mathrm{sec}$ ) throughout the year. Similarly, a very low flow of water $\left(12 \mathrm{~m}^{3} / \mathrm{sec}\right)$ from Pasig River, Manila, makes it one of the most contaminated rivers in the world [28]. Therefore, it is re-confirmed that the optimum river-flow has a dynamic role in pollution remediation especially for HMs in the polluted urban rivers.

\section{Policy Implications and Future Research Perspective}

Industries of urban areas altogether consume significant amounts of groundwater and create large volumes of polluted discharge. Thus, urban areas are suffering a shortage of sustainable water quality. As an active solution, government organizations can take necessary steps to maintain optimum recommended water-flow in the urban rivers as a part of the Delta Plan, 2100 (BDP 2100), announced by Bangladesh Government.

i. To ensure the minimum required water-flow in the urban river, a policy should be ensured for continuous $49.87 \mathrm{~m}^{3} / \mathrm{sec}$ water-flow from up-stream for sustainable water quality throughout the year.

Table 5. Flow-coefficients for different metals.

\begin{tabular}{|c|c|c|c|c|c|}
\hline \multirow{2}{*}{ Metal } & \multicolumn{5}{|c|}{ Flow co-efficient* } \\
\cline { 2 - 6 } & $P_{1}$ & $P_{2}$ & $P_{3}$ & $P_{4}$ & $P_{5}$ \\
\hline $\mathrm{Cr}$ & 0.2827 & -0.7139 & 0.6245 & 0.0516 & -0.102 \\
\hline $\mathrm{Cd}$ & 0.2827 & -0.1166 & 0.3163 & -0.2226 & 0.1449 \\
\hline $\mathrm{Pb}$ & 0.2827 & -0.8739 & 0.7266 & 0.04106 & -0.1207 \\
\hline $\mathrm{Cu}$ & 0.2827 & 0.5948 & 0.0044 & -0.0577 & 0.0309 \\
\hline $\mathrm{Mn}$ & 0.2827 & -0.9271 & 0.7583 & -0.1025 & 0.305 \\
\hline $\mathrm{Fe}$ & 0.2827 & -1.357 & 1.889 & -0.4841 & 0.8169 \\
\hline $\mathrm{Zn}$ & 0.2827 & -0.3767 & 0.3 & -0.0375 & 0.2045 \\
\hline $\mathrm{Ni}$ & 0.2827 & -0.6587 & 0.4855 & -0.0289 & 0.1009 \\
\hline
\end{tabular}

* with $95 \%$ confidence intervals

Table 6. The level of heavy metal concentration for the minimum required water-flow.

\begin{tabular}{|c|c|c|c|c|c|c|c|c|c|}
\hline & Metal & $\mathrm{Cr}$ & $\mathrm{Cd}$ & $\mathrm{Pb}$ & $\mathrm{Cu}$ & $\mathrm{Mn}$ & $\mathrm{Fe}$ & $\mathrm{Zn}$ & $\mathrm{Ni}$ \\
\hline \multicolumn{2}{|c|}{ Bangladesh standard (ppm) } & 0.5 & 0.5 & 0.1 & 0.5 & 0.3 & 1 & 5 & 0.1 \\
\hline \multirow{2}{*}{ Experimental } & Minimum Water -Flow $\left(\mathrm{m}^{3 /} \mathrm{sec}\right)$ & 33.13 & 27.64 & 20.10 & - & 33.13 & 49.87 & - & 33.82 \\
\hline & Concentration (ppm) & 0.218 & 0.390 & 0.008 & - & 0.267 & 0.911 & - & 0.064 \\
\hline \multirow{2}{*}{ Analytical } & Minimum Water- flow (m³/sec) & \multicolumn{8}{|c|}{49.87} \\
\hline & Concentration (ppm) & 0.095 & 0.005 & BDL & 0.126 & 0.099 & 0.911 & 0.091 & BDL \\
\hline
\end{tabular}

BDL- Below Detection Level 
It should be included in the 'Five Years Development Plan of Bangladesh' as well. Additionally, no further encroachment of the land down the river should be ensured.

ii. In the Water Act of Bangladesh, 2013, there is a provision for using groundwater for industrial and irrigation purposes. However, some stakeholders suggested that there should be bans on the extensive withdrawal of groundwater. As an alternative, river water can be utilized after maintaining an optimum flow of $49.87 \mathrm{~m}^{3} / \mathrm{sec}$.

iii. A sustainable institutional framework, mentioning the requirement of the optimum flow of $49.87 \mathrm{~m}^{3} / \mathrm{sec}$, can be put in place for the Bangladesh Water Development Board (BWDB) to implement the Master Plan (BDP 2100) for sustainable water management.

iv. Presently, Water Resources Planning Organization (WARPO) is officially responsible for implementing the Water Act of Bangladesh, 2013. WARPO may include the requirement of optimum water-flow in the water governance of Bangladesh.

v. Urban rivers in Bangladesh directly or indirectly receive large amounts of untreated industrial waste and effluents from a range of industries. These actors are not well aware of water issues or their exposure to water hazards imposed by their industries. Therefore, after being informed, illegal industries that distort the natural channel should be removed immediately from the riverbank.

\section{Conclusions}

Increased HMs concentration and loss of water-flow can have a detrimental effect on the ecological health of any urban river and its surrounding area. Compared to the other rivers in Bangladesh and around the world, the Turag River has been consistently exposed to a variety of HMs contamination. Thus, this river captured a more comprehensive scenario to investigate the correlation between HMs concentration and waterflow. The concentration of the selected heavy metals was evaluated in the water. Moreover, its current state has been compared to other countries and rivers around the world. The current state of the HMs concentration is frightfully exceeded the EQS for Bangladesh. The water-flow rate has also been observed to have reduced by more than $80 \%$ in the past two decades. Variation in the concentration of HMs was analyzed with the water-flow, distance from pollution sources, and different seasons (i.e., wet and dry). An empirical relation between $\mathrm{HMs}$ concentration and waterflow has been modeled and investigated to tackle the risk of HMs in river water. Thereby, a minimum waterflow requirement of $49.87 \mathrm{~m}^{3} / \mathrm{sec}$ has been analytically determined and verified to maintain the permissible level of HMs concentration for the ecological balance of the river.
Formulation of necessary policies and their strict enforcement is to be immediately ensured to increase the water-flow to minimize the perilous states of HMs concentration in the river water. The proposed modeling and analysis of the minimum water-flow requirement could also be studied for the other rivers as a pragmatic solution to tackle the risk of HMs and to save the ecological balance of the river and its surrounding area. Implementing of this method to the other polluted urban rivers of the world, optimum water-flow can be estimated as a part of their sustainable development program.

\section{Acknowledgements}

The assistance of Dr. Hussain Nyeem and Dr. Mostafizur Rahman, with their useful suggestions and proof-reading, is noted with gratitude. The authors also highly acknowledge the assistance of Jahangirnagar University and the Atomic Energy Research Institute for providing technical supports.

\section{Conflicts of Interest}

The authors declare no conflict of interest.

\section{References}

1. RAHMAN M.A.T.M., MOLY S.H. \& SAADAT A.H.M. Environmental flow requirement and comparative study of the Turag River, Bangladesh. International Journal of Scientific Research in Environmental Sciences 1, 291, 2013.

2. CHENG S. Effects of heavy metals on plants and resistance mechanisms. Environmental Science and Pollution Research, 10, 256, 2003.

3. YU S., YU G.B., LIU Y., LI G.L., FENG S., WU S.C. \& WONG M.H. Urbanization Impairs Surface Water Quality: Eutrophication and Metal Stress in The Grand Canal of China. River Research and Applications, 28, 1135, 2011.

4. ZHU D., WU S., HAN J., WANG L. \& QI M. Evaluation of nutrients and heavy metals in the sediments of the Heer River, Shenzhen, China. Environmental Monitoring and Assessment, 190, 380, 2018.

5. WASEEM A., ARSHAD A., IQBAL F., SAJJAD A., MEHMOOD Z., MURTAZA G. Pollution Status of Pakistan: A Retrospective Review on Heavy Metal Contamination of Water, Soil, and Vegetables. BioMed Research International, 2014, 1, 2014.

6. RAHMAN M.A., RAHMAN S.H., CHOWDHURY M.A.Z., FARDOUS Z. Impacts of Low Flows on Heavy Metal concentrations in Turag River Bangladesh. Journal of Environmental Science and Natural Resources, 10, 177, 2017.

7. GRIMM N.B., FAETH S.H., GOLUBIEWSKI N.E., REDMAN C.L., WU J., BAI X., BRIGGS J.M. Global change and the ecology of cities. Science, 319, 756, 2008.

8. RAHMAN A.K.M.L., ISLAM M., HOSSAIN M.Z., AHSAN M.A. Study of the seasonal variations in Turag 
river water quality parameters. African Journal of pure and applied Chemistry, 6, 144, 2012.

9. KAYE J.P., GROFFMAN P.M., GRIMM N.B., BAKER L.A., POUYAT R.V. A distinct urban biogeochemistry? Trends in Ecology \& Evolution, 21, 192, 2006.

10. MOKADDES M.A.A., NAHAR B.S., BATEN M.A. Status of Heavy Metal Contaminations of River Water of Dhaka Metropolitan City. Journal of Environmental Science and Natural Resources, 5, 349, 2013.

11. AHMED K.S., RAHMAN A.K.M.L., SARKAR M., ISLAM J.B., JAHAN I.A., MONIRUZZAMAN M., SAHA B., BHOUMIK N.C. Assessment on the level of contamination of Turag river at Tongi area in Dhaka. Bangladesh Journal of Scientific and Industrial Research, 51, 193, 2016.

12. ABDEL-SATAR A.M., ALI M.H., GOHER M.E. Indices of water quality and metal pollution of Nile River, Egypt. The Egyptian Journal of Aquatic Research, 43, 21, 2017.

13. OLIAS M., NIETO J.M., SARMIENTO A.M., CERÓN J.C., CÁNOVAS C.R. Seasonal water quality variations in a river affected by acid mine drainage: the Odiel River (South West Spain). Science of the total environment, 333, 267, 2004.

14. CHARKHABI A. H., SAKIZADEH M. \& RAFIEE G. Seasonal Fluctuation in Heavy Metal Pollution in Iran's Siahroud River-A Preliminary Study (7 pp). Environmental Science and Pollution Research, 12, 264, 2005.

15. SABIR M.A., SHAFIQ-UR-REHMAN S., UMAR M., WASEEM A., FAROOQ M., KHAN A.R. The Impact of Suspended Sediment Load on Reservoir Siltation and Energy Production: a Case Study of the Indus River and Its Tributaries. Polish Journal of Environmental Studies, 22, 219, 2013.

16. REZA R., SINGH G. Heavy metal contamination and its indexing approach for river water. International Journal of Environmental Science \& Technology, 7, 785, 2010.

17. LI N., TIAN Y., ZHANG J., ZUO W., ZHAN W., ZHANG J. Heavy metal contamination status and source apportionment in sediments of Songhua River Harbin region, Northeast China. Environmental Science and Pollution Research, 24, 3214, 2017.

18. BASHAR T., FUNG I.W.H. Water Pollution in a densely populated megapolis, Dhaka. Water, 12(8), 2124, 2020.

19. WANG J., LIU X.D., LU J. Urban river pollution control and remediation. Procedia Environmental Sciences, 13, 1856, 2012
20. HUGHES R.M., DUNHAM S., MAAS-HEBNER K.G., YEAKLEY J.A., SCHRECK C., HARTE M., MOLINA N., SHOCK C.C., KACZYNSKI V.W., SCHAEFFER J. A review of urban water body challenges and approaches: (1) rehabilitation and remediation. Fisheries, 2; 39 (1), 18, 2014.

21. SEPTIONO M.A.,ROOSMINI D. Heavy metal distribution in water, sediment and fish at upper Citarum river and its potential exposure pathway to human. In Proceedings of the $5^{\text {th }}$ Environmental Technology and Management Conference, Bandung, Indonesia, 23, 2015.

22. DoE \& LGED. Limited environment \& social impact assessment and environmental \& social management framework Bangladesh; Department of Environment and Local Government Engineering Department, Bangladesh; Vol. 1, 2010.

23. RABBANI M.L., SARKER S. Pollution Sources Assessment of Turag River, Bangladesh. IOSR Journal of Mechanical and Civil Engineering, 14, 84, 2017.

24. EQS (Environmental Quality Standard). Bangladesh Gazette, Registered. Department of Environment, Ministry of Environmentand Forest, Government of Bangladesh, 1997.

25. ABDEL-GHANI N.T., ELCHAGHABY G. A. Influence of operating conditions on the removal of $\mathrm{Cu}, \mathrm{Zn}, \mathrm{Cd}$ and $\mathrm{Pb}$ ions from wastewater by adsorption. Int. J. Environ. Sci. Technol., 4, 451, 2007.

26. SPENCER K.L, DEWHURST R.E., PENNA P. Potential impacts of water injection dredging on water quality and eco-toxicity in Lime house Basin, River Thames, SE England, UK. Chemosphere 63 (3), 509, 2006.

27. CICCHELLA D., GIACCIO L., LIMA A., ALBANESE S., COSENZA A., CIVITILlO D., DE VIVO B. Assessment of the topsoil heavy metals pollution in the Sarno River basin, south Italy. Environmental Earth Sciences, 1:71 (12), 5129, 2014.

28. GORME J.B., MANIQUIZ M.C., SONG P., KIM L.H. The water quality of the Pasig River in the city of Manila, Philippines: current status, management and future recovery. Environmental Engineering Research, 15 (3), 173,2010 . 